\title{
PERLINDUNGAN HUKUM TERHADAP KORBAN PELANGGARAN HAK KEKAYAAN INTELEKTUAL
}

\section{LEGAL PROTECTION FOR VICTIMS OF INTELLECTUAL PROPERTY RIGHT VIOLATIONS}

\author{
Alfredo Juniotama Arifin \\ Universitas Tarumanagara, Jakarta \\ alfredo.205200049@stu.untar.ac.id \\ Ruth Elizabeth Marlamb Putri \\ Universitas Tarumanagara, Jakarta \\ ruth.205200123@stu.untar.ac.id \\ Tiara Patricia \\ Universitas Tarumanagara, Jakarta \\ $\underline{\text { tiara.205200176@stu.untar.ac.id }}$
}

\begin{abstract}
Abstrak
Dalam menjalankan usaha, setiap produsen yang memiliki suatu karya harus diapresiasi atas karyanya tersebut. Bentuk apresiasinya bisa dilakukan dengan cara mendaftarkan karyanya untuk mendapatkan hak atas kekayaan intelektual agar dapat dilindungi oleh hukum. Hak Kekayaan Intelektual (HKI) adalah hak eksklusif yang diberikan suatu hukum atau peraturan kepada seseorang atau sekelompok orang atas karya ciptanya. Di Indonesia HKI belum terlaksanakan secara baik karena kurangnya sosialisasi dari pemerintah dan kurangnya kepedulian dari masyarakat. Hal ini mendorong pemerintah Indonesia untuk lebih peduli terhadap pelanggaran hak cipta. Seiring proses pelaksanaannya tidak dapat dipungkiri bahwa masih banyak oknum-oknum yang tidak mematuhi dan menggunakan suatu karya untuk kepentingan komersil. Metode penelitian yang digunakan adalah metode penelitian yuridisnormatif. Contoh kasus pada tanggal 13 Januari 2020, Ruben Samuel Onsu menggugat I Am Geprek Bensu milik PT. Benny Sujono atau disingkat dengan I Am Geprek Bensu dengan gugatan penyalahgunaan merek. Perlu adanya pengawasan pemerintah terhadap penggunaan karya cipta orang lain, koordinasi yang baik antara pemerintah dengan masyarakat sehingga dapat meminimalkan cela kesempatan untuk melakukan kecurangan terhadap suatu karya. Berdasarkan hasil telaah kasus-kasus yang terjadi, bahwa korban pelanggaran HKI dilindungi oleh hukum berdasarkan sistem first to file.
\end{abstract}

Kata Kunci: Hak Kekayaan Intelektual, Perlindungan Hukum, Korban Pelanggaran Hak Kekayaan Intelektual 


\begin{abstract}
In running a business, every producer who has a work must be appreciated for his work. The form of appreciation can be done by registering his work to get intellectual property rights so that it can be protected by law. Intellectual Property Rights (IPR) are exclusive rights granted by a law or regulation to a person or group of people for their copyrighted works. In Indonesia IPR has not been implemented properly due to lack of socialization from the government and lack of concern from the community. This encourages the Indonesian government to be more concerned about copyright infringement. Along with the implementation process, it is undeniable that there are still many individuals who do not comply and use a work for commercial purposes. The research method used is the juridicalnormative research method. For example, on January 13, 2020, Ruben Samuel Onsu sued I Am Geprek Bensu belonging to PT. Benny Sujono or abbreviated as I Am Geprek Bensu with a trademark abuse lawsuit. There is a need for government supervision of the use of other people's copyrighted works, good coordination between the government and the community so as to minimize the opportunity to commit fraud against a work. Based on the results of the study of cases that occurred, that victims of IPR violations are protected by law based on a first to file system.
\end{abstract}

Keywords : Intellectual Property Rights, Legal Protection, Intellectual Property Rights Violation Victims

\section{A. Pendahuluan}

Pada zaman yang modern ini dalam perkembangan iptek serta kegiatan pembangunan nasional telah memperbaiki segala aspek tatanan kehidupan masyarakat. Oleh karena itu, dibutuhkan upaya merumuskan dan memutakhirkan segala peraturan yang mengatur untuk mendapatkan jaminan kepastian hukum. Bidang iptek, sastra, dan juga seni yang memiliki keterkatian erat dengan masalah yang menyangkut hak kekayaan intelektual. Terdapat peningkatan sejumlah kegiatan dibidang teknologi yang ditandai dengan munculnya penemuan baru yang inovatif, tetapi sangat disayangkan, dalam perkembangan iptek, kesadaran masyarakat dan pelaku usaha industri belum secara jujur memahami pentingnya melindugi hak atas kekayaan intelektual suatu produk.

Hak Kekayaan Intelektual (HKI) dapat timbul karena adanya kemampuan intelektual dari manusia. Permasalahan HKI dalam masyarakat terus berkembang, dari masalah yang awalnya sederhana secara terus menerus menjadi semakin kompleks. Sudah saatnya semua pihak memberikan perhatian perlindungan hak atas kekayaan intelektual agar terciptanya 
kondisi yang kondusif untuk penciptaan dan perkembangan suatu karya yang inovatif dan kreatif di kehidupan sosial.

Sebagai bagian dari hukum niaga, keberadaan kekayaan intelektual mengalami perkembangan setiap tahun, baik dalam hal peningkatan pendaftaran kekayaan intelektual maupun pemahaman masyarakat tentang konsep perlindungan kekayaan intelektual. Hak Intelektual telah membawa berbagai perubahan terhadap suatu karya. Masalah kekayaan intelektual dapat melibatkan berbagai aspek, seperti industri, teknologi, budaya, masyarakat, dan aspek lain. Aspek yang paling penting dalam melindungi kekayaan intelektual adalah aspek hukum.

Masyarakat berharap hukum dapat menyelesaikan berbagai permasalahan terkait pelanggaran hak atas kekayaan intelektual. Undang-undang harus mampu memberikan perlindungan terhadap karya kekayaan intelektual sehingga berkembang kreativitas masyarakat yang pada akhirnya mengarah pada keberhasilan perlindungan kekayaan intelektual. Keterbatasan penghargaan suatu karya kini lebih diapresiasi dengan adanya undang-undang yang mengatur atas hak kekayaan intelektual.
Konsep Hak Kekayaan Intelektual (HKI) menurut Abdulkadir Muhammad ${ }^{1}$ adalah:

a. Hak milik produk dari pemikiran yang terhubung pada pemilik, sifatnya konsisten, dan eksklusif; dan

b. Hak yang didapatkan oleh orang lain atas izin dari si pemilik karya, sifatnya sementara.

Menurut Muhammad Djumhana dan R. Djubaedillah ${ }^{2}$, berikut prinsip-prinsip yang harus terkandung pada sistem HKI:

a. Prinsip Keadilan (the principle of natural justice)

Orang yang bekerja menghasilkan suatu karya dari kemampuan intelektualnya, berhak memperoleh imbalan baik berupa materi maupun bukan materi seperti rasa aman karena merasa dilindungi dan diakui atas karyanya. Perlindungan ini tidak hanya terbatas dalam negeri saja melainkan di luar batas negaranya. Hal ini karena hak yang ada mewajibkan pihak lain untuk melakukan atau tidak melakukan suatu perbuatan;

\footnotetext{
Abdulkadir Muhammad, Kajian Hukum Ekonomi Hak Kekayaan Intelektual, (Bandung: PT. Citra Aditya Bakti, 2001), hlm. 1-3.

${ }^{2}$ Muhammad Djumhana dan R. Djubaedillah, Hak Milik Intelektual Sejarah, Teori dan Prakteknya di Indonesia, (Bandung: PT. Citra Aditya Bakti, 1997), hlm. 19.
} 
b. Prinsip Ekonomi (the principle of economic)

Hak Kekayaan Intelektual (HKI) merupakan hak hasil dari pemikiran kreatif manusia yang diekspresikan dalam berbagai macam wujud dan manfaat dalam menunjang kehidupan masyarakat, karena ini dapat memberikan keuntungan bagi pemiliknya, contohnya dalam bentuk pembayaran royalti;

c. Prinsip Kebudayaan (the principle of cultural)

Dengan tumbuh dan berkembangnya ilmu pengetahuan, seni, dan sastra sangat berarti besar untuk meningkatkan taraf hidup, peradaban, dan martabat masyarakat. Pengakuan atas karya cipta seseorang dibakukan dalam sistem hak kekayaan intelektual merupakan hal yang tidak dapat lepas sebagai bentuk untuk menghidupkan semangat dan menciptakan karya baru; dan

d. Prinsip Sosial (the principle of social) Hukum mengatur kepentingan manusia sebagai warga masyarakat sehingga terjadi ikatan kemasyarakatan. Hukum juga memberikan hak untuk perseorangan atau persekutuan yang berguna bagi seluruh masyarakat. ${ }^{3}$

Secara umum, Hak Kekayaan Intelektual terbagi atas 2 (dua) jenis, yaitu: Hak Cipta dan Hak Kekayaan Industri yang meliputi paten, merek, desain industri, desain tata letak sirkuit terpadu, rahasia dagang, dan varietas tanaman. Hak Kekayaan Intelektual (HKI) telah diatur dalam berbagai perundang-undangan, yaitu UU No. 28 Tahun 2014 (Hak Cipta), UU No. 13 Tahun 2016 (Paten), UU No. 20 Tahun 2016 (Merek dan Indikasi Geografis), UU No. 31 Tahun 2000 (Desain Industri), UU No. 32 Tahun 2000 (Desain Tata Letak Sirkuit Terpadu), UU No. 30 Tahun 2000 (Rahasia Dagang), UU No. 29 Tahun 2000 (Varietas Tanaman).

Salah satu permasalahan yang sering terjadi di Indonesia ialah banyaknya korban pelanggaran atas hak kekayaan intelektual yang karya ciptanya dilakukan secara illegal untuk mendapatkan kepentingan komersil. Berdasarkan laporan $\mathrm{CNN}$ Indonesia sepanjang tahun 2019, Kementrian Hukum dan HAM (KEMENKUMHAM) mencatat pelanggaran merek sebagai hal yang paling banyak diadukan. Jumlah yang masuk ke Direktorat Jendral Kekayaan Intelektual

3 Heri Firmansyah, Perlindungan Hukum terhadap Merek : PanduanMemahami Dasar Hukum Penggunaan dan Perlindungan Merek,(Yogyakarta: MedPress, 2013), hlm. 7. 
(DJKI) kemenkumham adalah pelanggaran merek (34 aduan) disusul aduan pelanggaran hak cipta (7 aduan), hak paten (2 aduan), dan desain industri (4 aduan) dengan total 47 aduan yang diterima DJKI terhadap pelanggaran kekayaan intelektual sepanjang tahun 2019. ${ }^{4}$ Banyaknya seniman, komposer, pengusaha dan penulis buku yang dirugikan. Tentunya hal ini mengakibatkan buruknya pandangan orang terhadap suatu karya dan banyaknya orang yang dirugikan oleh hal tersebut. Pemerintah Indonesia telah melakukan sejumlah upaya-upaya dan pengambilan kebijakan dengan cara mengatur dengan undang-undang yang tersebut di atas.

Kejahatan pelanggaran hak kekayaan Intelektual dapat menyebabkan kerusakan substansial dan non-materil bagi penggunanya dan juga dapat membahayakan kehidupan bangsa dan negara. kejahatan di dunia maya lahir dari akibat dampak negatif perkembangan teknologi. Kejahatan tersebut terjadi dalam berbagai bentuk dan jenis ini akan mempengaruhi perlindungan hukum penggunanya. Hal ini penting mengingat setiap orang harus dilindungi sebagaimana mestinya sebagai martabat manusia.

\footnotetext{
${ }^{4}$ https://www.cnnindonesia.com/teknologi/2019 1231141341-185-461331/pelanggaran-merekpaling-banyak-diadukan-ke-kemenkumham, diakses tanggal 5 Maret 2021, pukul 15.00 WIB.
}

Dari sudut pandang kriminologi, kejahatan tidak hanya merupakan tindakan yang melanggar hukum atau hukum pidana, tetapi juga mencakup setiap jenis perilaku anti sosial, bahkan jika perilaku tersebut tidak dibatasi oleh undang-undang atau hukum pidana, namun merugikan masyarakat. Selama ini sanksi atas pelanggaran hak atas kekayaan intelektual belum menimbulkan efek jera bagi pelanggar, sehingga meskipun pemerintah telah memberlakukan undang-undang, angka pelanggarannya terus meningkat. Penegakan hukum yang kuat dan konsisten sangat penting untuk memberikan perlindungan kekayaan intelektual, namun pencegahan pelanggaran lebih penting untuk meningkatkan kualitas warga negara Indonesia. Oleh karena itu, perlu dilakukan refleksi menyeluruh atas kinerja pemerintah dalam memberikan perlindungan hukum terhadap Hak Kekayaan Intelektual serta menjelaskan mengenai konsep dasar dari Hak Kekayaan Intelektual.

\section{B. Metode Penelitian}

Sesuai dengan judul, rumusan masalah, dan tujuan penelitian ini, yaitu untuk memberikan manfaat berupa informasi, maka metode penelitian yang digunakan dalam penelitian ini adalah metode penelitian yuridis-normatif. 
Metode penelitian yuridis-normatif adalah metode penelitian dimana hukum dioperasikan sebagai kaidah atau norma yang merupakan patokan berperilaku manusia yang dianggap pantas. Penelitian Hukum Normatif ini didasarkan kepada bahan hukum primer dan sekunder, yaitu penelitian yang mengacu pada normanorma yang terdapat pada peraturan perundang-undangan.

Penelitian yuridis-normatif ini berguna untuk mendapatkan bahan-bahan penelitian berupa teori, asas, konsep, dan peraturan hukum yang berhubungan dengan pokok bahasan.

\section{Pembahasan}

\section{Pengertian Perlindungan Hukum}

Perlindungan hukum adalah untuk melindungi hak asasi manusia yang dirugikan oleh orang lain dan memberikan perlindungan tersebut kepada masyarakat agar mereka dapat menikmati semua hak yang diatur oleh undang-undang, baik perlindungan bersifat preventif maupun represif, baik secara tertulis maupun tidak tertulis. Perlindungan hukum digambarkan sebagai suatu fungsi hukum dimana hukum dapat memberikan keadilan, kepastian, ketertiban, kemanfaatan, dan kedamaian.
Suatu perlindungan dapat dikatakan sebagai perlindungan hukum apabila mengandung unsur-unsur sebagai berikut:

a) Terdapat pengayoman dari pemerintah terhadap warga;

b) Kepastian hukum;

c) Sanksi bagi pelanggar;

d) Berkaitan dengan hak warga negara.

Sarana perlindungan hukum sebagai tempat dalam pelaksanaannya untuk memberikan perlindungan hukum dibagi menjadi 2 (dua), yaitu:

1) Sarana Perlindungan Hukum Preventif Sarana ini dipergunakan untuk subjek hukum yang akan diberikan kesempatan mengajukan keberatan atau pendapatnya sebelum suatu keputusan pemerintah, tujuannya untuk mencegah terjadinya perselisihan. Perlindungan ini sangat penting untuk kebebasan bertindak. Dengan sarana perlidungan hukum preventif diharapkan pemerintah dapat lebih berhati-hati dalam memutuskan berdasarkan diskresi. Perlindungan hukum preventif di Indonesia masih belum memiliki aturan khusus.

2) Sarana Perlindungan Hukum Represif Sarana perlindungan hukum ini memiliki tujuan untuk menyelesaikan perselisihan. Perlindungan hukum yang masuk ke dalam kategori ini di Indonesia adalah penanganan 
perlindungan hukum oleh Pengadilan

Umum dan Pengadilan Administrasi.

Prinsip perlindungan hukum dari tindakan pemerintah berasal dari konsep pengakuan dan perlindungan hak asasi manusia untuk membatasi dan memperjelas kewajiban masyarakat dan pemerintah.

\section{Konsep Dasar Mengenai Hak Kekayaan Intelektual}

Istilah mengenai Hak Kekayaan Intelektual (HKI) merupakan terjemahan yang berasal dari Intellectual Property Right (IPR). IPR adalah hal yang mengatur segala karya yang lahir dari kemampuan intelektual manusia dan mempunyai hubungan dengan hak seseorang secara pribadi. IPR diatur dalam Undang-undang No. 7 Tahun 1994 tentang Pengesahan WTO (Agreement Establishing The World Trade Organization). ${ }^{5}$

Ruang lingkup Hak Kekayaan Intelektual (HKI) terdiri atas Hak Cipta dan Hak Kekayaan Industri. Hak cipta itu sendiri didalamnya termasuk bidang ilmu pengetahuan, seni, dan kesusastraan. Sedangkan, hak industri merupakan hak

\footnotetext{
${ }^{5}$ Ardian, A. V, Prospek Perlindungan Hukum Hak Kekayaan Intelektual Dalam Kesenian Tradisional Di Indonesia, 2008. Doctoral dissertation, program Pascasarjana Universitas Diponegoro.
}

yang khusus berkenaan dengan bidang industri yang meliputi paten, merek, desain industri, desain tata letak sirkuit terpadu, rahasia dagang, dan varietas tanaman.

Berikut akan dijabarkan mengenai ruang lingkup Hak Kekayaan Intelektual seperti penjabaran di atas:

a) Hak Cipta (UU No. 28 Tahun 2014)

Pengertian hak cipta menurut Undang-undang Nomor 28 Tahun 2014 tentang Hak Cipta diatur dalam Pasal 1 angka 1 adalah hak istimewa bagi pencipta setelah karya tersebut ditampilkan dalam bentuk nyata, yang mana secara otomatis akan dihasilkan sesuai dengan prinsip deklaratif, dan tidak akan dikurangi menurut ketentuan hukum.

Pengertain hak terkait menurut Undang-undang Nomor 28 Tahun 2014 mengenai hak terkait diatur dalam Pasal 1 angka 5 adalah hak eksklusif yang memiliki kaitan dengan hak cipta bagi pelaku pertunjukkan, produser, fonogram, atau lembaga penyiaran.

Hal ini dirancang untuk memberikan perlindungan hukum bagi pemegang hak cipta yang bekerja keras untuk menciptakan lingkungan pertumbuhan yang lebih baik, serta hak cipta merupakan bagian dari hak 
kekayaan intelektual yang ruang lingkup objek dilindunginya paling luas, yaitu mencakup ilmu pengetahuan, seni, dan sastra dimana di dalamnya juga mencakup pula program komputer.

Berdasarkan Pasal 4 Undangundang Nomor 28 Tahun 2014 tentang Hak Cipta menyatakan bahwa Hak Cipta merupakan hak eksklusif yang terdiri dari hak moral dan hak ekonomi. Menurut Pasal 5, Hak Moral merupakan hak yang melekat secara abadi pada diri pencipta. Sedangkan, menurut Pasal 8, Hak Ekonomi merupakan hak istimewa yang dimiliki Pemilik Hak Cipta untuk mendapatkan keuntungan ekonomi atas Ciptaannya. ${ }^{6}$

Untuk mendapatkan perlindungan melalui hak cipta, tidak ada keharusan untuk mendaftarkan. Pendaftaran hanya semata-mata untuk keperluan pembuktian belaka. Dengan demikian, begitu suatu ciptaan berwujud, maka secara otomatis hak cipta melekat pada hasil karya cipta tersebut. Perlindungan mengenai hak cipta tidak dapat diperuntukkan kepada ide atau gagasan, karena suatu karya

\footnotetext{
${ }^{6}$ Undang-Undang Nomor 28 Tahun 2014 tentang Hak Cipta
}

wajib memiliki wujud yang khusus, sifatnya pribadi, dan menampilkan keaslian sebagai karya cipta yang terwujud dari kemampuan, kreatifitas atau keahlian, sehingga suatu karya cipta tersebut bisa dilihat, dibaca atau didengar. $^{7}$

Masa perlindungan hak cipta adalah seumur hidup pencipta +70 tahun, untuk program komputer 50 tahun sejak dipublikasikan untuk pertama kali, untuk pelaku jangka waktu perlindungannya adalah 50 tahun sejak pertama kali dipertunjukkan, untuk produser rekaman adalah 50 tahun sejak ciptaan difiksasikan, dan untuk lembaga penyiaran adalah 20 tahun sejak disiarkan pertama kali. ${ }^{8}$

Bentuk perlindungan yang diberikan termasuk siapa yang dilarang hanya terbitkan atau menyalin karya yang dilindungi kecuali dengan izin dari pemilik hak cipta, sebagai pengecualian, disebutkan atau menyertakan sumber tidak dianggap sebagai pelanggaran hak cipta.

\footnotetext{
$7 \quad$ https://penelitian.ugm.ac.id/hak-cipta/, diakses tanggal 10 Maret 2021, pukul 11.00 WIB

https://www.dgip.go.id/menu-utama/hakcipta/pengenalan, diakses tanggal 10 Maret 2021, pukul 10.15 WIB.
} 
b) Paten (UU No. 13 Tahun 2016)

Pengertian paten menurut Undang-undang Nomor 13 Tahun 2016 tentang Paten diatur dalam Pasal 1 angka 1 adalah hak ekslusif yang didapatkan inventor atas produk invensinya dari negara, yang untuk jangka waktu tertentu secara sendiri atau memberikan izinnya untuk orang lain untuk melaksanakannya invensinya. ${ }^{9}$

Invensi adalah gagasan yang berasal dari inventor yang dimasukkan ke dalam suatu kegiatan untuk menyelesaikan permasalahan di bidang teknologi, dapat berupa produk atau proses atau perbaikan dan pengembangan produk atau proses.

Untuk mendapatkan hak paten, suatu invensi harus memenuhi beberapa persyaratan, yaitu baru dimana tidak boleh dipublikasikan oleh media manapun sebelum permohonan patennya diajukan dan memperoleh tanggal penerimaan, mengandung langkah inventif, dan dapat diterapkan dalam industri.

9 Undang-Undang Nomor 13 Tahun 2016 tentang Paten
Terdapat dua jenis hak paten, yaitu paten dan paten sederhana. Perbedaan antara paten dan paten sederhana adalah paten diberikan untuk gagasan baru yang mengandung kreativitas dan dapat diterapkan dalam industri. Sedangkan, paten sederhana diberikan untuk setiap gagasan baru yang dikembangkannya dari hasil atau proses yang telah ada tetapi harus memiliki fungsi atau kegunaan yang lebih praktis daripada invensi sebelumnya, dan dapat diterapkan dalam industri.

Masa perlindungan paten adalah untuk jangka waktu 20 tahun sejak tanggal diterimanya permohonan paten, sedangkan masa perlindungan paten sederhana adalah untuk jangka waktu 10 tahun sejak tanggal diterimanya permohonan paten sederhana. $^{10}$

c) Merek dan Indikasi Geografis (UU No. 20 Tahun 2016)

Pengertian merek menurut Undang-undang Nomor 20 Tahun 2016 tentang Merek dan Indikasi Geografis diatur dalam Pasal 1 angka 1 adalah simbol yang dapat

\footnotetext{
${ }^{10}$ https://www.dgip.go.id/menuutama/paten/pengenalan, diakses tanggal 6 Maret 2021, pukul 11.15 WIB
} 
ditampilkan dalam bentuk grafik seperti gambar, logo, nama, kata, huruf, angka, warna, ukuran 2 (dua) dan/atau 3 (tiga) dimensi, suara, hologram, atau kombinasi, atau salah satu unsur atau lebih untuk membedakan barang dan/atau jasa yang dihasilkan oleh perorangan atau badan hukum dalam perdagangan barang dan/atau jasa.

Menurut Undang-undang Nomor 20 Tahun 2016 dalam Pasal 1 angka 5 menyatakan bahwa hak atas merek adalah hak istimewa bagi pemilik merek terdaftar yang diberikan oleh negara untuk jangka waktu tertentu untuk dapat menggunakan sendiri atau memberikan izin kepada pihak lain untuk menggunakan mereknya.

Pengertian indikasi geografis menurut Undang-undang Nomor 20 Tahun 2016 diatur dalam Pasal 1 angka 6 adalah tanda yang menunjukkan tempat asal suatu produk, karena faktor lingkungan geografis (termasuk faktor alam, faktor manusia, atau kombinasi dari kedua faktor tersebut), yang memberikan produk tersebut reputasi, kualitas, dan karakteristik tertentu.

Menurut Undang-undang Nomor 20 Tahun 2016 dalam pasal 1 angka 7 mengenai hak atas indikasi geografis adalah hak istimewa bagi pemegang hak indikasi geografis terdaftar yang diberikan negara, selama masih ada reputasi, kualitas, dan karakteristik dasar diberikannya perlindungan hukum atas indikasi geografis. ${ }^{11}$

Pendaftaran merek dagang berfungsi sebagai tanda bagi pemilik yang berhak atas merek yang didaftarkan, sebagai dasar untuk menolak merek yang sama secara menyeluruh atau sama pada intinya yang telah dimohonkan pendaftarannya oleh orang lain untuk barang/jasa sejenisnya, sebagai dasar untuk mencegah orang lain memakai merek yang sama secara keseluruhan atau pada pokoknya dalam hal pernyebaran untuk barang/jasa sejenisnya.

Jangka waktu perlindungan hukum merek dan indikasi geografis adalah 10 tahun sejak tanggal diterimanya permohonan pendaftaran yang bersangkutan dan jangka waktu tersebut dapat diperpanjang dalam jangka waktu 6 (enam) bulan sebelum

\footnotetext{
${ }^{11}$ Undang-Undang Nomor 20 Tahun 2016 tentang Merek dan Indikasi Geografis
} 
berakhirnya jangka waktu perlindungan bagi merek terdaftar. ${ }^{12}$

d) Desain Industri (UU No. 31 Tahun 2000)

Pengertian desain industri menurut Undang-undang Nomor 31 Tahun 2000 tentang Desain Industri diatur dalam Pasal 1 angka 1 adalah Sebuah kreasi yang terkait dengan bentuk, konfigurasi atau komposisi garis atau warna, atau kombinasi dengan tiga atau dua dimensi, dapat memberikan rasa keindahan, dan dapat diwujudkan dalam tiga atau dua dimensi; dan dapat digunakan untuk menghasilkan produk, barang industri atau kerajinan tangan.

Menurut Pasal 1 angka 5 Undangundang Nomor 31 Tahun 2000 menyatakan bahwa hak desain industri adalah hak eksklusif oleh negara kepada Pendesain atas hasil kreasinya untuk dalam jangka waktu tertentu melakukan sendiri, atau memberikan persetujuannya kepada pihak lain untuk melaksanakan hak tersebut. ${ }^{13}$

Desain industri hanya dapat didaftarkan jika baru, dengan

\footnotetext{
12 https://www.dgip.go.id/menuutama/merek/pengenalan, diakses tanggal 6 Maret 2021, pukul 12.00 WIB

13 Undang-Undang Nomor 31 Tahun 2000 tentang Desain Industri
}

ketentuan pada tanggal penerimaan permohonan pendaftaran, desain tersebut berbeda dari pengungkapan sebelumnya dan tidak bertentangan dengan peraturan perundangundangan yang berlaku, ketertiban umum, atau keyakinan atau moralitas agama. $^{14}$

Jangka waktu perlindungan terhadap desain industri adalah 10 tahun terhitung sejak tanggal diterimanya permohonan pendaftaran dan tidak dapat dilakukan perpanjangan perlindungan. ${ }^{15}$

e) Desain Tata Letak Sirkuit Terpadu (UU No. 32 Tahun 2000)

Pengertian desain tata letak sirkuit terpadu menurut Undangundang Nomor 32 Tahun 2000 tentang Desain Tata Letak Sirkuit Terpadu diatur dalam Pasal 1 angka 1 mengenai sirkuit terpadu adalah Suatu produk jadi atau setengah jadi yang didalamnya terdapat berbagai elemen, paling sedikit salah satunya adalah

\footnotetext{
${ }^{14}$ https://www.dgip.go.id/menu-utama/desainindustri/pengenalan, diakses tanggal 6 Maret 2021, pukul 17.00 WIB.

${ }^{15}$ https://penelitian.ugm.ac.id/10067-

2/\#: :text=Perlindungan\%20terhadap\%20Hak\%20 Desain\%20Industri,tidak\%20dapat\%20dilakukan\% 20perpanjangan\%20perlindungan, diakses 7 Maret 2021, pukul 10.15 WIB.
} 
elemen aktif, yang sebagian atau seluruhnya saling berhubungan dan dibentuk secara terintegrasi dalam suatu bahan semikonduktor yang dimaksudkan untuk menghasilkan fungsi elektronik. Sedangkan, dalam Pasal 1 angka 2 mengenai desain tata letak adalah dibuat dalam bentuk desain tata letak tiga dimensi dari berbagai elemen, setidaknya salah satu elemen tersebut merupakan elemen aktif, dan sebagian atau seluruh interkoneksi dalam suatu sirkuit terpadu, dan tata letak tiga dimensi ditujukan untuk pembuatan sirkuit terintegrasi.

Menurut Pasal 1 angka 6 Undangundang Nomor 32 Tahun 2000 tentang Desain Tata Letak Sirkuit Terpadu menyatakan bahwa Hak Desain Tata Letak Sirkuit Terpadu adalah hak eksklusif yang diberikan oleh Negara Republik Indonesia kepada penciptanya, yang dapat melaksanakan pekerjaannya sendiri atau menyetujui kepada pihak lain untuk menggunakan hak tersebut dalam jangka waktu tertentu. ${ }^{16}$

\footnotetext{
${ }^{16}$ Undang-Undang Nomor 32 Tahun 2000 tentang Desain Tata Letak Sirkuit Terpadu
}

Syarat terdaftarnya desain tata letak sirkuit terpadu adalah jika desain tata letak sirkuit terpadu itu asli, desain tersebut adalah karya independen dari desainer yang tidak umum bagi pendesain saat desain tata letak sirkuit terpadu itu dibuat.

Jangka waktu perlindungan desain tata letak industri adalah 10 tahun sejak pertama kali desain tata letak industri dieksploitasi secara komersial atau sejak tanggal diterimanya permohonan pendaftaran. ${ }^{17}$

f) Rahasia Dagang (UU No. 30 Tahun 2000)

Pengertian rahasia dagang menurut Undang-undang Nomor 30 tahun 2000 tentang Rahasia Dagang diatur dalam Pasal 1 angka 1 mengenai Rahasia Dagang adalah informasi yang tidak diketahui masyarakat di bidang teknologi dan / atau bisnis, serta memiliki nilai ekonomis karena berguna dalam kegiatan usaha dan dirahasiakan oleh pemilik Rahasia Dagang. ${ }^{18}$

\footnotetext{
17 https://www.dgip.go.id/menuutama/dtlst/pengenalan, diakses tanggal 7 Maret 2021, pukul 16.20 WIB

18 Undang-Undang Nomor 30 Tahun 2000 tentang Rahasia Dagang
} 
Ruang lingkup perlindungan Rahasia Dagang meliputi metode produksi, metode pengolahan, metode penjualan, atau informasi lain di bidang teknologi dan/atau bisnis yang memiliki nilai ekonomi dan tidak diketahui oleh masyarakat umum.

Pelanggaran Rahasia Dagang terjadi apabila seseorang dengan sengaja mengungkapkan Rahasia Dagang, mengingkari kesepakatan atau mengingkari kewajiban tertulis atau tidak tertulis untuk menjaga Rahasia Dagang yang bersangkutan; seseorang memperoleh atau menguasai Rahasia Dagang dengan cara yang bertentangan dengan peraturan perundang-undangan yang berlaku. Untuk jangka waktu perlindungan rahasia dagang tidak memiliki batas waktu perlindungan. ${ }^{19}$

g) Varietas Tanaman (UU No. 29 Tahun 2000)

Pengertian varietas tanaman menurut Undang-undang Nomor 29 Tahun 2000 tentang Varietas Tanaman diatur dalam Pasal 1 angka 3 mengenai varietas tanaman yang selanjutnya disebut varietas adalah sekelompok jenis tumbuhan yang

\footnotetext{
${ }^{19}$ https://www.dgip.go.id/menu-utama/rahasiadagang/pengenalan, diakses tanggal 9 Maret 2021, pukul 11.15 WIB.
}

bercirikan bentuk tumbuhan, pertumbuhan tumbuhan, daun, bunga, buah, biji, dan ekspresi ciri genotipe atau kombinasi genotipe. Ciri atau kombinasi genotipe tersebut dapat melewati paling sedikit satu sifat yang ditetapkan dan apabila diperbanyak tidak mengalami perubahan.

Menurut pasal 1 angka 2 Undangundang Nomor 29 Tahun 2000, Hak Perlindungan Varietas Tanaman adalah hak istimewa yang diberikan negara dalam hal ini pelaksanaannya dilakukan oleh Kantor Perlindungan Varietas Tanaman kepada pemulia dan/atau pemegang hak Perlindungan Varietas Tanaman untuk menggunakan sendiri varietas hasil pemuliaannya atau memberi persetujuan kepada orang atau badan hukum lain untuk menggunakannya selama waktu tertentu.

Jangka waktu perlindungan perlindungan varietas tanaman adalah selama 20 tahun untuk tanaman semusim dan 25 tahun untuk tanaman tahunan dihitung sejak tanggal diterimanya permohonan pendaftaran varietas tanaman. ${ }^{20}$

\footnotetext{
${ }^{20}$ Undang-Undang Nomor 29 Tahun 2000 tentang Varietas Tanaman
} 


\section{Contoh Kasus Pelanggaran Hak Kekayaan Intelektual}

Munculnya pelanggaran Hak Kekayaan Intelektual membuat para pengusaha dan seniman menjadi khawatir terutama pada hal hak cipta dan hak patennya. Hal ini menyebabkan ketidakpercayaannya para pengusaha dan seniman terhadap pemerintah yang terkesan acuh tak acuh terhadap peraturan yang diimplementasikan. Seperti contoh kasus sengketa merek yang dialami oleh Benny Sujono melawan Ruben Onsu. Ruben Onsu menggugat Benny Sujono terhadap kasus penggunaan merek "BENSU" Ruben Onsu menganggap Benny Sujono telah melanggar sengketa merek. Pada tanggal 23 Agustus 2019 bahwa penggugat telah mendaftar ke kepaniteraan Pengadilan Niaga pada Pengadilan Negeri Jakarta Pusat, bahwa penggugat adalah pemilik hak dan pendaftar pertama atau (first to file) atas merek "BENSU". Menurut penggugat merek "BENSU" telah dimohonkan secara bertahap sejak tanggal 08 Agustus 2017 sampai 31 Juli 2018 terdaftar pada tanggal 07 Juni 2018 dan merek "BENSU" telah mendapatkan perlindungan sampai tanggal 03 September 2025, tetapi dalam pokok perkara bahwa tidak benar pengggugat sebagai pemilik pertama dan sebagai pihak pertama yang mendaftarkan merek
"BENSU" sebagaimana terbukti berdasarkan pada tanggal 03 September 2015 bahwa sebagai pemilik hak merek "BENSU" yang terdaftar, Jessy Handallim telah mempergunakan hak merek "BENSU" sebagai merek susu yang diperdagangkannya dilokasi suatu bengkel yang terletak di Jalan Emong No.3, Burangrang, Bandung, sehingga merek "BENSU" tersebut adalah diambil dari singkatan nama "BENGKEL SUSU". ${ }^{21}$

\section{Kesimpulan}

Dari penjelasan yang telah diuraikan di atas maka dapat disimpulkan bahwa pengertian dari Hak Kekayaan Intelektual adalah terjemahan dari Intellectual Property Right (IPR) yang mengatur mengenai segala karya yang lahir dari kemampuan intelektual manusia dan bersifat privat dan eksklusif.

a) Hak Cipta

Bentuk perlindungan hukum pelanggaran hak cipta diatur dalam Undang-Undang Nomor 28 Tahun 2014 tentang Hak Cipta adalah paling lama pidana penjara 4 (empat) tahun dengan

\footnotetext{
${ }^{21}$ https://putusan3.mahkamahagung.go.id/direk tori/download file/401662cf0d7a7e3f5af5b6e5 28399993/pdf/a080714ce66bfd8d6d1e449b8b 35a52c, diakses tanggal 10 Maret 2021, pukul 20.20 WIB
} 
denda paling banyak Rp 4.000.000.000,00

(empat miliar rupiah). ${ }^{22}$

b) Paten

Bentuk perlindungan hukum pelanggaran paten diatur dalam UndangUndang Nomor 13 Tahun 2016 tentang Paten adalah paling lama pidana penjara 10 (sepuluh) tahun dengan denda paling banyak Rp 3.500.000.000,00 (tiga miliar lima ratus juta rupiah). ${ }^{23}$

c) Merek dan Indikasi Geografis

Bentuk perlindungan hukum pelanggaran merek dan indikasi geografiis diatur dalam Undang-Undang Nomor 20 Tahun 2016 tentang Merek dan Indikasi Geografis adalah paling lama 10 (sepuluh) tahun dengan denda paling banyak $\mathrm{Rp}$ 5.000.000.000,00 (lima miliar rupiah). ${ }^{24}$

d) Desain Industri

Bentuk perlindungan hukum pelanggaran desain industri diatur dalam Undang-Undang Nomor 31 Tahun 2000 tentang Desain Industri adalah pidana paling lama 4 (empat) tahun dengan denda Rp 300.000.000,00 (tiga ratus juta rupiah). ${ }^{25}$

e) Desain Tata Letak Sirkuit Terpadu

\footnotetext{
22 Ibid hal 6

${ }^{23}$ Ibid hal 6

${ }^{24}$ Ibid hal 7

${ }^{25}$ Ibid hal 8
}

Bentuk perlindungan hukum pelanggaran desain tata letak sirkuit terpadu diatur dalam Undang-Undang Nomor 32 Tahun 2000 tentang Desain Tata Letak Sirkuit Terpadu adalah pidana paling lama 3 (tiga) tahun dengan denda paling banyak Rp 300.000.000,00 (tiga ratus juta rupiah). ${ }^{26}$

f) Rahasia Dagang

Bentuk perlindungan hukum bagi pelanggaran rahasia dagang diatur dalam Undang-Undang Nomor 30 Tahun 2000 adalah pidana penjara 2 (dua) tahun dengan denda paling banyak $\mathrm{Rp}$ $300.000 .000,00$ (tiga ratus juta rupiah). ${ }^{27}$

g) Varietas Tanaman

Bentuk perlindungan hukum atas varietas tanaman diatur dalam UndangUndang Nomor 29 Tahun 2000 adalah pidana penjara 7 (tujuh) tahun dengan denda paling banyak Rp 2.500.000.000,00 (dua miliar lima ratus juta rupiah). ${ }^{28}$

Hak Kekayaan Intelektual telah diatur dan diberlakukan dengan sedemikian rupa di dalam Undang-Undang. Akan tetapi, dalam implementasi fakta di lapangan ternyata masih banyak terjadi pelanggaran Hak Kekayaan Intelektual dengan alasan seseorang tidak mengetahui tentang

\footnotetext{
${ }^{26}$ Ibid hal 8

${ }^{27}$ Ibid hal 9

${ }^{28}$ Ibid hal 9
} 
keberadaan Hak Kekayaan Intelektual itu sendiri. Maka dari itu, peran pemerintah sangat penting untuk menyosialisasikan pentingnya Hak Kekayaan Intelektual kepada Masyarakat.

\section{Daftar Pustaka}

\section{Buku}

Abdulkadir Muhammad, Kajian Hukum Ekonomi Hak Kekayaan Intelektual, Bandung: PT. Citra Aditya Bakti, 2001.

Heri Firmansyah, Perlindungan Hukum terhadap Merek : PanduanMemahami Dasar Hukum Penggunaan dan Perlindungan Merek, Yogyakarta: MedPress, 2013.

Muhammad Djumhana dan R. Djubaedillah, Hak Milik Intelektual Sejarah, Teori dan Prakteknya di Indonesia, Bandung: PT. Citra Aditya Bakti, 1997

\section{Karya Ilmiah}

Ardian, A. V, Prospek Perlindungan Hukum Hak Kekayaan Intelektual Dalam Kesenian Tradisional Di Indonesia, Doktoral dissertation, Program Pascasarjana Universitas Diponegoro, 2008.

\section{Peraturan Perundang - Undangan}

Undang-Undang Nomor 29 Tahun 2000 tentang Varietas Tanaman

Undang-Undang Nomor 30 Tahun 2000 tentang Rahasia Dagang

Undang-Undang Nomor 31 Tahun 2000 tentang Desain Industri
Undang-Undang Nomor 32 Tahun 2000 tentang Desain Tata Letak Sirkuit Terpadu

Undang-Undang Nomor 28 Tahun 2014 tentang Hak Cipta

Undang-Undang Nomor 13 Tahun 2016 tentang Paten

Undang-Undang Nomor 20 Tahun 2016 tentang Merek dan Indikasi Geografis

\section{Website}

https://www.cnnindonesia.com/teknologi/2 0191231141341-185-

461331/pelanggaran-merek-palingbanyak-diadukan-ke-kemenkumham, diakses tanggal 5 Maret 2021, pukul 15.00 WIB.

https://penelitian.ugm.ac.id/hak-cipta/, diakses tanggal 10 Maret 2021, pukul 11.00 WIB

https://www.dgip.go.id/menu-utama/hakcipta/pengenalan, diakses tanggal 10 Maret 2021, pukul 10.15 WIB.

https://www.dgip.go.id/menuutama/paten/pengenalan, diakses tanggal 6 Maret 2021, pukul 11.15 WIB

https://www.dgip.go.id/menuutama/merek/pengenalan, diakses tanggal 6 Maret 2021, pukul 12.00 WIB

https://www.dgip.go.id/menuutama/desain-industri/pengenalan, diakses tanggal 6 Maret 2021, pukul 17.00 WIB.

https://penelitian.ugm.ac.id/10067-

2/\#: :text=Perlindungan\%20terhada p\%20Hak\%20Desain\%20Industri,tid 
ak\%20dapat\%20dilakukan\%20perpa njangan\%20perlindungan, diakses 7 Maret 2021, pukul 10.15 WIB.

https://www.dgip.go.id/menuutama/dtlst/pengenalan, diakses tanggal 7 Maret 2021, pukul 16.20 WIB

https://www.dgip.go.id/menuutama/rahasia-dagang/pengenalan, diakses tanggal 9 Maret 2021, pukul 11.15 WIB.

https://putusan3.mahkamahagung.go.id/dir ektori/download_file/401662cf0d7a7 e3f5af5b6e528399993/pdf/a080714c e66bfd8d6d1e449b8b35a52c, diakses tanggal 10 Maret 2021, pukul 20.20 WIB 